ISSN 2080-1653

DO1 10.24917/20801653.324.6

\author{
HANNA GODLEWSKA-MAJKOWSKA \\ Warsaw School of Economics, Poland
}

\title{
Polarity of the Regional Space - the Dilemma of Shaping the Investment Attractiveness of Poland
}

\begin{abstract}
This study aims to show how the polarisation of the economic space can modify the investment attractiveness of the regional space. A thesis has been put forward that the polarisation of the economic space affects the investment attractiveness of the regional space by strengthening the polarising power of the regions with the highest investment attractiveness. This study uses the results of the parameterisation of investment attractiveness of Polish regions for 2015 by gmina; it also identifies growth poles in four five-year time periods: 2008-2012, 2009-2013, 2010-2014, and 2011-2015. The study shows that the permanent growth poles are created at a distance of several dozen kilometres from large cities. It indicates the depletion of development reserves of large and medium-sized cities, especially those with extensive space management. Smaller centres are gaining location attractiveness, especially those located in the vicinity of communication routes, where access to investment areas and lower costs of running a business attract investors. Special economic zones are also located in such places. The poles and their clusters usually form large agglomerations and industrial centres in the development phase. They are usually places with high investment attractiveness, adjusted by management decisions of large enterprises, local government units and the state government. The polarisation of the economic space affects the increase of the investment attractiveness of the regions, strengthening the succession of economic production and service functions in special economic zones. Investments in road infrastructure and revitalisation processes supported by special economic zones are essential.
\end{abstract}

Keywords: growth pole; investment attractiveness of the region; investments; local development; location

Received: 1 July 2018

Accepted: 16 September 2018

\section{Suggested citation:}

Godlewska-Majkowska, H. (2018). Polarity of the Regional Space - the Dilemma of Shaping the Investment Attractiveness of Poland. Prace Komisji Geografii Przemysłu Polskiego Towarzystwa Geograficznego [Studies of the Industrial Geography Commission of the Polish Geographical Society], 32(4), 110-122. https://doi. org/10.24917/20801653.324.6

\section{INTRODUCTION}

Economic space is affected by simultaneous tendencies to polarise and increase homogeneity. Most classical theories in this regard come from the assumption of homogeneity 
of space and indicate that even in such a theoretical, model space, polarising forces come to the fore. Even if all resources and people are evenly spaced, Christaller's centres or growth poles described by F. Perroux will be created.

In economic practice, two opinions about local and regional development clash. One is based on the forces of concentration of capital and markets indicating its economic benefits. On the other hand, there are programs activating economically poorly developed areas or projects equalising differences in this respect, for example under the European Union's cohesion policy. The issue of finding a balance and complementing each other in the space of these two opposing phenomena is, therefore, an issue worth analysing for the deployment of new investments, especially in industry.

Investments are usually created in places attractive from the investor's point of view, i.e. characterised by investment attractiveness. Attractive places can be created by the central or local government unit through an investment policy, for example through tax incentives and by increasing the standard of the investment product offered at the locations for activation, restructuring or revitalisation.

The question arises, however, whether such activities should have a spatially concentrated nature, or instead take on a dispersed system, according to the needs of the local scale. How should this be influenced by the already existing polarisation, which is usually the core of further changes in spatial structures? Can the polarisation phenomena resulting from long-term spatial development trends be modified as a result of phenomena that cannot be managed by either entrepreneurs or public stakeholders? These include the disadvantages of the scale, disadvantages of the neighbourhood, domino effect, the effect of monoculture or of being influenced by foreign decision-making centres. For example, the phenomena mentioned above modify the seemingly apparent effect of space polarisation on investment attractiveness, and thus the ability to attract investment and stimulate local and regional development.

Therefore, the question arises whether there are limits to the concentration of investments in a given place. If so, how to take it into account when there is an overlap of various types of development waves coming from different decision centres? How does it affect the already existing polarisation understood as a process?

It is, therefore, a very complex phenomenon, which in this article, due to its volume, is mainly indicated by many years of research by the author and a review of world literature devoted to the issues raised.

This study aims to show how the polarisation of economic space can modify the investment attractiveness of regional space. Therefore, an attempt will be made to prove the thesis that the polarisation of economic space affects the investment attractiveness of regional space by strengthening the polarising power of the regions with the highest investment attractiveness. This study uses the results of parameterisation of investment attractiveness of Polish regions divided into gminas, poviats and voivodeships, conducted by the Warsaw School of Economics, due to the possibility of making comparative analyses at the level of gminas, which is unique for this research centre.

\section{ON THE ESSENCE OF THE POLARITY OF SPACE}

In the literature, the process of formation of growth poles and polarisation of regions at various taxonomic levels is widely described (e.g. Churski, 2014). Many studies point to the leading role of the French economist F. Perroux, who stated that the 
unsustainable nature of economic growth, both spatially and in sectoral terms, can be mitigated by the growth poles (Perroux, 1964). Polarisation can cause both positive and negative effects, which has already been expressed via the identification of both stimulation/induction effects and inhibition. Therefore, polarisation may not occur as expected by investors, because they may face the exceedance of the optimal level of the scale of their operations, both in spatial and sectoral terms. O. Hirschman also perceived the positive and negative context of the poles as the endpoints of the axes, in which he combined the positive effects with infiltration and the negative ones with polarisation (Grzeszczak, 1999).

The cited authors are the classics of the approach, which indicates that the polar nature of development makes it necessary to stimulate the existing poles. However, there is a risk of over-stimulation, which ultimately leads to the weakening of the growth of the poles in the absence of the activation of peripheral areas and thus the consolidation or even deepening of spatial disparities. Hence, the remedy is to create growth poles as a result of substantial investments supporting the development of previously poorly economically developed areas thanks to state interventions (Myrdal, 1968). This is possible thanks to the liberation of development forces affecting both the creation of demand for goods and services in the motor unit, as well as the creation of jobs, and thus increasing consumer and investment demand.

At the same time, the geographical location of a given region relative to the centre of a given space is essential. Moving away from the centre, investments, income and technological advancement decrease (Henderson, Shelizi, Venables, 2001). Therefore, the investment attractiveness of the peripheral area located at an excessive distance from the growth pole is lower.

The growth pole is thus a distinct centre of space, polarising it and developing faster than its surroundings. For this study, it is assumed that a growth pole is the centre of the polarised region emitting developmental stimuli, and showing higher growth dynamics compared to the rest of the region. The region can be referred to spatial units of various levels of taxonomic division (e.g. local, meso-regional, macro-regional) (Godlewska-Majkowska, Komor, Typa, 2016).

The formation of poles, and thus the polarisation of space, is caused by phenomena occurring in space, often parallel, or in the form of waves of various length, initiated at different times. From the point of view of the polarisation of space, developmental waves are essential, caused by groundbreaking inventions that increase the importance of attractiveness of specific places in a given period. On this principle, we can indicate poles formed in the 19th and 20th century as a result of industrial investments during the industrial revolution based on coal and steel, and poles based on the IT revolution, the so-called silicon landscapes, created in the second half of the 20th century.

Every epochal innovation requires different conditions to flourish in a given place. Waves with new innovative solutions are transferred in areas with poorly outlined barriers to the assimilation of innovations, while, in turn, require much time to trigger important changes in places where barriers may not only cause that the given innovative idea does not reach but its source is even destroyed.

The overlap of developmental waves, running at different speeds, or even omitting some areas, causes that polarisation takes place in varying degrees and with different strength in particular places of the economic space. In Poland, an example of this may be the persistence of the high level of industrialisation in south-western Poland, as a 
result of overlapping successive waves of innovations, while the level of industrialisation in Podlasie remains low.

The carrier of changes can be a sizeable individual investor, a state investment directed at the activation of the region, or the bottom-up concentration of numerous small businesses.

Historically shaped poles based on large enterprises with several thousand employees and with high ease of creating a network of cooperative relations in line with the concept of growth poles had an uncomplicated ownership structure. Thus, they were independent of other entities. Nevertheless, they often required numerous co-operators or companies integrated vertically or horizontally, in order to optimise operational processes. It is how the combined plants, i.e. large factory complexes, developed, jointly using the infrastructure, or creating numerous market links thanks to the benefits of diversity.

This type of processes led to the formation of industrial centres and districts, which in subsequent stages were natural points strengthening the polarisations of their natural regional surrounding. To this day, it is visible in the form of concentration of industrial enterprises in cities of at least medium size, as well as agglomerations. This mechanism explains the general principle that the more polarised a region is, the higher the investment attractiveness of its pole or group of poles.

Looking at the map of Poland's attractiveness, or broader Europe, one can notice the attractiveness of large cities and their suburban areas that stand out on this map, while rural areas, especially peripheral ones, are still less attractive and are not subject to polarisation that allows investors to be interested in large or numerous investments, even in sectors based on the latest technologies, less susceptible to economies of scale.

Polarisation of space can occur according to different spatial patterns. It has a monocentric course when a leading industry sector in a given location is susceptible to large-scale benefits or when a given settlement unit has a significant urbanisation benefit. If a large city has developed in a given place and nothing disturbs the commercial functions of such a centre, the importance of individual poles, i.e. nodes organising the polarised region, grows with the growing scale of trade. If we deal with a city-forming function based on a raw material factor and a dispersed system of mine location, then the nuclei of groups close to each other are created, which gives rise to conurbations, or nodal regions of the dispersed type.

A polarised system may also have a linear form organised following the course of natural boundaries, e.g. along the coast, an example of which may be the Gdańsk agglomeration. Natural conditions organise changes to this spatial arrangement, as exemplified by the impact of the port in Gdynia on the creation of a bicentric region in the Gdańsk agglomeration. This example also shows the significant role of state policy and the use of the investment potential of a given place. The construction of the port in Gdynia is a good example of the investment attractiveness of this place in the interwar period.

Polarisation can also take place by increasing the intensity from the outside of the pole to its centre and vice versa, according to the stage of urbanisation processes. In the urbanisation phase, centripetal tendencies prevail, as exemplified by investment placement in the central part of the city, then in the suburbanisation phase the importance of suburban areas especially attractive for investments requiring mechanisation of works and convenient access for numerous suppliers and recipients increases. In the final phase of re-urbanisation, the importance of the centre may grow again, especially 
in the phase of expanding multi-storey construction serving as a location environment for small businesses based on the benefits of diversity. At this stage, the development of post-industrial areas in the form of brownfield and the creation of new multifunctional centres accelerating the revitalisation of degraded post-industrial areas brings significant benefits.

Growth poles are usually places with high investment attractiveness, which results from higher growth dynamics compared to the environment and visible above-average socio-economic effects, expressed through measures reflecting various aspects of the socio-economic development. Poles polarising the regional space do not always cause an increase in investment attractiveness, which leads to the weakening of the self-perceiving effect of the investment attractiveness of regions with a traditionally high rating. It is due to the currently high bargaining position of enterprises in the direct investment market. It can be said that large corporations even impose the polarisation of a given area, indicating which locations they consider attractive or increasing their attractiveness due to the promise of generating jobs in a specific place, where it will be counted as an economic success, regardless of durability of the generated jobs and income transfer.

The problem is that the areas polarised by companies independent of the state implement their strategy, not always taking into account the good of their local or regional environment. It is because the management of a given company is obliged to respect the owners' interest, and thus higher puts the benefit of the production units located in the investor's country of origin than in the foreign branch, even when it is highly profitable and provides stable growth prospects. Therefore, ultimately, the attractiveness of a given place does not have to be adequate to real business opportunities occurring in a given place, resulting from cross-links and polarisation in a given place, but it can be reduced. Such a situation may occur if resources allowing for economic development in a given region have been exhausted, and growing barriers are not levelled in accordance with infrastructure overloads related to exceeding the thresholds for development. There may also be a slowdown in development or even a recession as a result of adverse phenomena of a natural or social nature (e.g. uncontrolled inflow of population not adequate to the capacity of a given settlement centre).

In turn, places with a low concentration of resources or market capacity may be more attractive due to the system of economic incentives. It is particularly true for sites with tax incentives or attracted by local business activity zones. Therefore, the actual distribution of growth poles can be a reflection of not only the processes of concentration of production and population, but can also be found in places perceived by investors as attractive for other reasons.

\section{POLARISED REGIONS IN POLAND}

Growth poles are usually big cities with their suburban areas. This type of conclusion flows, among others, from E. Wojnicka's research, which determined the growth poles in Pomorskie and Podkarpackie Voivodeships based on data from the first decade of the 21st century.

The author took into account the following variables:

1. Population income - average gross income per capita in 2000-2006 with Poland's average equal 100 , as well as the dynamics of this income. 
2. The income of the population at the level of gminas was estimated on the basis of the gminas' income from the tax on natural persons by dividing these inflows by the product of the gminas' share in the tax in a given year and the effective tax rate on natural persons.

3. Entrepreneurship - change in the number of business entities in the REGON register in the gmina in 2006 as compared to 1995, and the number of business entities per 1000 inhabitants in 2006.

4. Profits of companies - legal entities - gross income of enterprises per capita in 2005-2006 estimated from gmina income from corporate tax and average dynamics of this income in the years 1999-2006.

5. Labour market - average dynamics of employees in the gmina in the years 19952006 and reverse dynamics of the unemployment rate in the poviat of 2006-2004.

6. Balance of migration - net migration of population for permanent residence to the gmina in the years 1995-2006. The calculated series of variable values for individual gminas were standardised to enable their joint analysis. (Wojnicka, 2007: 17).

Based on the results of the research for Pomorskie Voivodeship, E. Wojnicka identified growth poles in the form of the Gdańsk agglomeration together with the surrounding gminas. According to the author, "It can be estimated that in the Pomeranian region there is a process of concentration of strong growth in the Tri-City metropolis and its diffusion to the neighbouring gminas". In turn, in 2004-2008 the strongest growth poles in Podkarpackie Voivodeship were formed by the poviats of the Rzeszów metropolitan area, as well as single gminas with industrial functions (e.g. Leżajsk, Stalowa Wola, Sanok, and Mielec) and tourist centres (Iwonicz-Zdrój, Cisna) (Wojnicka-Sycz, 2012: 46-47).

Polarisation of the Polish space was also the subject of research by other authors, but all of them confirmed that large cities and their agglomerations are development poles. W. Gaczek indicates that in the years 2005-2012 "an obvious advantage prevailed of the economic growth of sub-regions of large cities over the peripheral areas of the country. Differences between the agglomeration centre (urban poviat) and adjacent areas in most of the seven agglomerations examined did not decrease. The greatest differences occurred in the geographic proximity of economic entities between Wrocław and the Wrocław subregion, and between Warsaw and Warsaw's eastern subregion, as well as between Szczecin and the Szczecin subregion. There were also significant differences between subregions of large cities and adjacent subregions regarding the unemployment rate and geographic proximity of entities in the service sections $\mathrm{K}, \mathrm{M}$ and N." (Gaczek, 2015: 28)

The study was based on the following variables: (1) gross domestic product per capita, (2) gross value added (GVA) per employee, (3) gross value of fixed assets and capital expenditures in enterprises per capita and sq $\mathrm{km}$, (4) population density and density of working population, (5) number of total economic entities and entities of selected sections per area unit, (6) average gross monthly remuneration, and (7) value of sold industrial production per capita.

This coincides with the investment attractiveness map. The differences between the polarisation map and investment attractiveness are limited to only a few categories of places: 
- Centres which can become poles are a place of business in transport hubs, where the local labour market has not developed, and income from business activities is discharged in the place where it is conducted. In this situation, the polarisation of a specialised nature precedes the creation of favourable conditions for attracting investment (lower investment attractiveness compared to the degree of polarisation),

- The centres are not poles if the potential of a given place has not been activated, for example by the lack of sufficient promotion of the place and its poor recognition or strong barriers to the development of local entrepreneurship or weak pro-entrepreneurial attitudes.

The factor influencing both the polarisation and the investment attractiveness are regulations leading to the disruption of competitive conditions in the form of areas privileged concerning tax. In Poland, these are regulations concerning special economic zones that are dynamically spreading all over Poland, but with uneven intensity in individual regions. It is known that most of them are in the regions with the strongest industrial traditions (Dolnośląskie Voivodeship), and the least in the regions with the lowest level of economic development, that is the opposite to the primary objective of their creation. Special economic zones can simultaneously enhance polarity and investment attractiveness, especially when they are created in the areas with unusually high location values. Besides, they may generate income and entrepreneurship that is ahead of the creation of the primary location advantages.

Economic subzones are located both in suburban areas of large cities or urban complexes, as well as in unattractive places, where the zone has been created for specific properties in the form of, for example, warehouses that are competitive due to a short time in which it is possible to adapt them to new functions. Even the best-prepared investment areas in desirable locations require time to start to generate profits, whereas in the era of generally smaller physical distances, the importance of economic distance and time distance is increasing.

Therefore, the question arises whether the creation of locational advantages and increasing investment attractiveness strengthens already existing growth poles, thus leading to further spatial concentration of economic activity in Poland, or rather a tendency to de-concentrate is visible, as a result of the increase in investment attractiveness of cities up to 100,000 inhabitants, constituting centres of at most sub-regional character, or as a result of the expansion of influence zones of big cities along the urbanisation paths. An attempt to answer such a question requires analysis at the gmina level because only on this scale it is possible to capture the impact of economically privileged areas or the influence of economic entities on the development dynamics of the various taxonomic regions. In the literature, analyses at the gmina level have appeared, but they often refer to the selected aspects of polarisation, for example to metropolitan processes, omitting the influence of the enterprise sector on the creation of growth poles (this group includes: Gaczek, 2010; Herbst, Wójcik, 2013).

Research based on a comparison of models built for each year separately and in relation to subregions or poviats, therefore, should be supplemented with analyses at the level of gminas. At this level, using several years' periods of time reflecting investment cycles, it is possible to identify the areas developing faster than their regional surroundings and thus achieving basic income, professional and economic effects. 


\section{IDENTIFICATION OF GROWTH POLES}

Based on the identification of growth poles with the local government unit, which shows faster economic development than the higher-order territorial unit (NUTS+1), it was assumed that if the territorial range of the gmina corresponds to the poviat, the reference unit is a taxonomic unit two ranks higher, i.e. subregion, and if the gmina corresponds to the poviat and the subregion at the same time, then the reference point is the voivodeship (NUTS2).

To identify growth poles the following variables were used:

1. business activity indicator - some entities registered in the REGON system per 1,000 people of working age,

2. employment rate - the number of people employed per 1,000 people of working age,

3. affluence ratio - a sum of shares in taxes constituting revenues of the state budget, personal income tax and shares in taxes constituting revenues of the state budget, corporate income tax per 1 person of working age.

The criteria for delimitation were as follows:

- the level of average annual dynamics of changes in the economic activity indicator in the analysed period and a comparison with the reference level (Z1);

- the level of average annual dynamics of changes in the employment rate in the analysed period and a comparison with the reference level (Z2);

- the level of average annual dynamics of changes in the rate of affluence in the analysed period and a comparison with the reference level (Z3).

The study was conducted in the following four five-year time periods: 2008-2012, 2009-2013, 2010-2014 and 2011-2015. This approach allowed for capturing the investment process in individual territorial units and the essential elements of the pole's impact on the local economy (entrepreneurship, professional activity and income effects) (more on the method: H. Godlewska-Majkowska, A. Komor, M. Typa, 2016). The results of the application of this method are presented in Fig. 1.

Local growth poles were defined in particular five-year periods. If all three components of the final ratio in a given period were above the value in the reference area, then the given commune was considered as a pole. If this occurred in only one period, then the pole received 4 points, if twice - 8 points, if three times - 12 points, and if four times - 16 points, i.e. the maximum rating, which means that in the entire period studied, the unit emitted more intensive developmental stimuli than the reference area, representing its regional or local surroundings, depending on its size.

In Fig. 1 we can see the existence of a cluster of growth poles in suburban zones of big cities, which shows that large cities delegate their development functions as part of the succession of city-forming functions. The poles also form along with essential communication routes thanks to the benefits associated with a convenient communication location, as well as in the gminas hosting special economic zones in their area. What is surprising, the map is missing large cities, even though they are strong economic centres. For example, Warsaw achieves better results regarding entrepreneurship development and an increase in economic activity of the population in relation to Mazowieckie Voivodeships. However, it has worse effects concerning tax revenue per capita. The same applies to Krakow and Łódź, which are the most significant Polish cities after Warsaw. 
Fig. 1. Local growth poles in the years 2008-2015 against the investment attractiveness of gminas in Poland in 2015

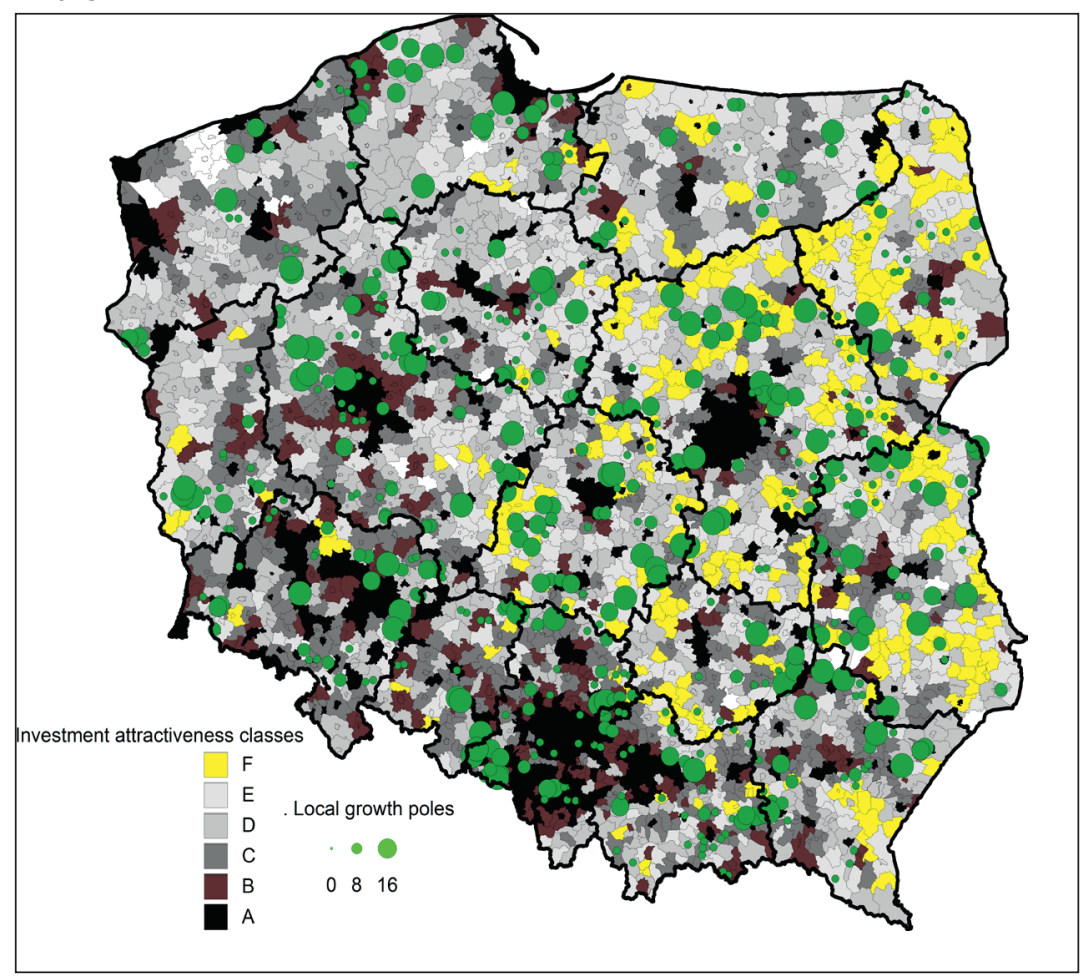

Source: own work based on the databases of the Institute of Enterprise

In Figure 1 we can see also differences between local units, based on assessment of potential investment attractiveness. Potential investment attractiveness is defined as a set of regional location advantages that influence achieving investors' goals (such as costs of running a business, sales revenues, net return on investment and investment's competitiveness).

Investment attractiveness index is based on weight-correlation method, allowing determination of weights of pseudo-attribute variables such as demographic factor, social and technical infrastructure, administration, economic market.

Investment attractiveness index PAI1 ranges from 0 to 1 . Classes have been defined for the purpose of comparative analyses. Their scope has been described by leftclosed intervals with the following lower bounds:

$$
\begin{aligned}
& \text { class A: } A v+S(x), \\
& \text { class B: } A v+0.5 S(x), \\
& \text { class } C: A v, \\
& \text { class D: } A v-0.5 S(x), \\
& \text { class E: Av }-\mathrm{S}(\mathrm{x}), \\
& \text { class F: } 0 \text {, } \\
& \text { where: }
\end{aligned}
$$

Av - arithmetic mean,

S(x) - standard deviation. For further details see: H. Godlewska-Majkowska (2012). 
The distribution of growth poles against the diversification of potential investment attractiveness allows us to observe certain regularities. Considering the occurrence of growth poles in the following five-year periods in 2008-2015, it can be noticed that they have the most durable character in the places of unusually high communication quality (Stryków - motorway junction), location along expressways (gminas between Słupsk and Tri-City), and along motorways (e.g. Kowalewo Pomorskie in Kujawsko-Pomorskie Voivodeship). Sometimes this is accompanied by revitalisation, such as, for example, in Zaleszany Gmina located along the national road 77.

The spatial layout of the most stable growth poles, i.e. those that emitted development stimuli throughout the analysed period, indicate that they are often located in the suburb zone of large cities, in the areas with high investment values (often of class A or B), as exemplified by the identified poles, e.g. Rokietnica near Poznań, Radziejowice in Żyrardów Poviat which is part of the Warsaw agglomeration, and Dąbrówka near Radzymin. These examples show the development of growth poles along the arms of urbanisation. In the vicinity of Wrocław, similar examples are provided by the rural gminas of Zawonia and Oława, as well as the rural-urban gmina of Jelcz-Laskowice. It is also possible to see growth poles whose development is triggered by special economic zones. These include gminas of Legnickie Pole and Jelcz-Laskowice, as well as Nowe Skalmierzyce.

Interesting is also the phenomenon of permanent development effects of gminas included in the lowest classes of attractiveness (e.g. F and E municipalities). These include the following gminas: Masłowice, Ciechanów, Trzebieszów, Klukowo, Kościelec, Kawęczyn, Mieścisko, Radowo Małe, Zawonia, Cisek, Prostki, Kruklanki, Żarnów, Czerwin, Międzyrzec Podlaski, Wysokie Mazowieckie, Waśniów, Łoniów, and Chrostkowo, as well as urban-rural gminas of Drzewica (3) and Wyśmierzyce (3). Their unique development in 2008-2015 has an impact on investment attractiveness, and probably shortly it will be possible to notice their advancement on the map of attractiveness.

The analysis of the map, therefore, shows that there is no direct relationship between the distribution of local growth poles and the distribution of large cities. Instead, it should be pointed out that they appear in places where extraordinary opportunities arise associated with new roads being built, or the depletion of investment areas in large agglomerations, thus more distant areas, but still within the isochrone of 60 minutes travel time to work, gain attractiveness. Other researchers also came to similar conclusions (f. e. Dębski, 2002, 2003; Instytut Badań nad Gospodarką Rynkową, 2007).

An important role is also played by companies making investments in special economic zones and places subjected to revitalisation processes, allowing the generation of new jobs, the increase of entrepreneurship and increase of income for the local population. It mainly applies to gminas under the influence of the Wrocław agglomeration and the Legnica-Głogów Copper District. However, this does not change the fact that big cities still maintain their strong position as growth poles, as evidenced by studies devoted to particular regions (more: Kudełko, 2016).

\section{MANAGEMENT OF INVESTMENT ATTRACTIVENESS AS A TASK OF REGIONAL AND LOCAL AUTHORITIES}

Shaping the investment attractiveness of the regions is a task that supports the coherent spatial development character of a given region, country or group of countries. If we refer to Poland, then it can be pointed out that the concepts of spatial development 
of the country have long been presented with the view that we should strive for bandnode development with moderate polycentrism, in which excessive concentration of economic activity in big cities is not allowed, but rather development opportunities for all Polish regions are created, striving for coherence of the created spatial structures, thanks also to the adaptation of the transport network to the needs of sustainable spatial development.

If we accept such assumptions, the question arises whether the investment attractiveness supports the desired direction of polarisation in the spatial development of the country. The analysis of changes in investment attractiveness shows the strengthening of the largest cities and the agglomerations they create on the maps of investment attractiveness, while the development of new poles is rare.

From the observations made in the period 2008-2015, it can be stated that the most attractive investment gminas included agglomerations of Warsaw, Katowice, Krakow, Łódź, Poznań, Szczecin, and Tri-City, which was associated with numerous location values of big cities and their urban complexes. The lowest investment attractiveness was demonstrated by gminas in eastern Poland, in particular, the Lublin, Podlasie, eastern Mazovia and eastern Subcarpathian regions.

Changes in investment attractiveness are the result of the certain inertia of the processes creating location assets, which results from the long-term nature of public investments and the impact of the gained experience in obtaining external financing for further investments. Thanks to the learning process and the reputation of big cities as places in which it is worth running a business, there is a natural limitation of the set of considered locations to a group of places relatively well known to investors or to places where investors who are a role model for others have already made investments.

This mechanism based on investors' behaviour explains why there is a positive effect of cumulative causality in places attracting investments, and with the negative cumulative causality in places that cannot interrupt the process of growing development barriers.

The consolidation of the current trends in creating the most attractive places also results from the persistence of permanent criteria as the leading location decision making process. The market factors, i.e. the size of the market and its dynamics, remain the leading criteria for the location. Since market factors are of the most vital importance, it becomes apparent why large agglomerations as markets and places with excellent communication with other cities of the same or higher size class maintain their attractiveness until they reach the limits of growth or succession of some functions in favour of their surroundings.

It is challenging to stand out for smaller centres located outside the zone of influence of growth poles. Therefore, changes allowing the implementation of the concept of polycentric development of the country may be achieved by initiatives supporting the development of investments based on endogenous growth factors. Valuable are all solutions supporting entrepreneurship - preparation of the offer of investment areas for the needs of local business environment along with business incubators, dissemination of business knowledge, organisation of initiatives supporting business networking, marketing activities or thoughtful creation of institutions that support attracting investment not only to a specific centre but also to a group of potential partners in the form of other settlement units or organisations. A public-public partnership, private-public 
partnership and active management of local development financing are examples of auxiliary activities.

\section{SUMMARY}

This study aimed to show how the polarisation of economic space can modify the investment attractiveness of regional space. Considering the fact that the polarity of space can be studied in various ways, it is worth emphasising that the literature prevails in the opinion that space poles, not only in Poland but also in other parts of the world, are large cities and that they naturally increase the polarisation of economies in different corners of the globe. Investment attractiveness is its reflection, as the most attractive areas are metropolitan areas and industrial or tourist centres. Nevertheless, on a local scale, these processes may be disturbed by spatial separation of jobs from population distribution or tax settlement. Developmental stimuli may be blurred, and the spheres most affected by local or regional development may shift away from agglomeration centres.

The study shows that growth poles of permanent nature are created at a distance of several dozen kilometres from large cities. It indicates the depletion of development reserves of large cities and medium-sized cities, especially those with extensive space management. Location centres are becoming smaller, mainly located in the vicinity of communication routes, where access to investment areas and lower costs of running a business attract investors. Special economic zones are also located in such places, giving benefits to investors interested in creating their value chains based on the existing connections. Often they are not interested in creating networks based on local suppliers and recipients. It gives the mosaic character of polarised space.

The poles and their clusters are usually formed by large agglomerations and industrial centres in the development phase. These are usually places with high investment attractiveness, but there are exceptions. In every investment cycle, there are periods of transitional opportunities for regions with lower investment risk, where less complex projects are more rational and reliable. Also, new markets may open that require other elements to build investment attractiveness. The changes in attractiveness can be adjusted by the strength of inertia of the processes that create location assets, including management decisions of large enterprises, local authorities and the state government. Polarisation of economic space thus influences the increase of the investment attractiveness of the regions, strengthening the succession of economic production and service functions in the zones. A considerable role in these processes is played by investments in road infrastructure and revitalisation processes supported by special economic zones.

\section{References}

Churski, P. (2014). Model polaryzacyjno-dyfuzyjny w przemianach polityki spójności - konsekwencje dla ukierunkowania polityki rozwoju (The polarisation-diffusion model in the transformation of cohesion policy - the consequences for the direction of development policy). Rozwój Regionalny i Polityka Regionalna, 25, 13-27.

Dębski, J. (2002). Lokalne bieguny wzrostu w Polsce na przełomie XX i XXI wieku. Tom II [Local growth poles in Poland at the turn of the 20th and 21st centuries. Part II]. Białystok: Wyższa Szkoła Finansów i Zarządzania. 
Dębski, J. (2003). Lokalne bieguny wzrostu w Polsce (według budżetów gmin i przedsiębiorczości prywatnej) [Local growth poles in Poland (according to budgets of gminas and private enterprise)]. Prace Komisji Geografii Przemysłu Polskiego Towarzystwa Geograficznego, 5, 31-59.

Gaczek, W.M. (2010). Miasta jako bieguny rozwoju w polskiej przestrzeni - polaryzacja czy konwergencja [Cities as poles of development in Polish space - polarisation or convergence]. Zeszyty Naukowe Wydawnictwa Uniwersytetu Adama Mickiewicza, 161, 88-109.

Gaczek, W.M. (2015). Bliskość geograficzna jako czynnik wzrostu gospodarczego w podregionach wielkich miast polskich [Geographic proximity as a factor of economic growth in subregions of large Polish cities]. Studia Oeconomica Posnaniensia, 3(8), 7-29.

Godlewska-Majkowska, H. (ed.) (2012). Atrakcyjność inwestycyjna regionów Polski jako źródło przedsiębiorczych przewag konkurencyjnych. Warszawa: Warsaw School of Economics.

Godlewska-Majkowska, H., Komor, A., Typa, M. (2016). Special Economic Zones as Growth and Anti-growth Poles as Exemplified by Polish Regions. Entrepreneurial Business and Economics Review, 4(4),189-212.

Grzeszczak, T. (1999). Bieguny wzrostu a formy przestrzeni spolaryzowanej [The poles of growth and forms of polarised space]. Prace Geograficzne,173, 11-14.

Henderson, J.V., Shelizi, Z., Venables, A.J. (2001). Geography and development. Journal of Economic Geography, 1(1), 81-105.

Herbst, M., Wójcik, P. (2013). Delimitacja dyfuzji rozwoju z miast metropolitalnych z wykorzystaniem korelacji przestrzennej [Delimitation of diffusion of development from metropolitan cities using spatial correlation]. Studia Regionalne i Lokalne, 4(54), 5-21.

Instytut Badań nad Gospodarką Rynkową (2007). Lokalne bieguny wzrostu [Local growth poles]. Pomorski Przegląd Gospodarczy, 4.

Kudełko, J. (2016). Centra wzrostu w regionie podkarpackim w latach 1980-2014 [Growth centers in the Podkarpackie region in 1980-2014]. Annales Universitatis Paedagogicae Cracoviensis Studia Geographica.

Myrdal, G. (1968). Asian drama: An Inquiry into the poverty of nations. New York: Twentieth Century Fund.

Perroux, F. (1964). L'Economie du XXe siècle [The economy of the 20th century]. Paris: PUF.

Wojnicka, E. (2007). A co na to statystyki [And what does statistics say?]. Pomorski Przegląd Gospodarczy, 4,16-21.

Wojnicka-Sycz, E., (2012). Innowacyjność branż a lokalne bieguny wzrostu w województwie podkarpackim [Innovation of industries and local growth poles in Podkarpackie Voivodeship]. Barometr Regionalny, 1(27), 37-50.

Hanna Godlewska-Majkowska, professor, Collegium of Business Administration, Vice Rector for Outreach, coordinator, Students' Scientific Group on Entrepreneurship and Regional Analyzes, Warsaw School of Economics. Research interests: location of enterprises, regional entrepreneurship investment attractiveness and competitiveness of regions, territorial marketing, Small and Medium Enterprises (sources of success, threats, intelligent organisations), financial management of local government units.

\title{
Address:
}

\author{
Warsaw School of Economics \\ Collegium of Business Administration \\ al. Niepodległości 162, 02-554 Warszawa, Poland \\ e-mail: hgodle@sgh.waw.pl
}

